\title{
ARBITRAŻ MIĘDZYNARODOWY W CHRL JAKO EFEKT GLOBALNEJ INTEGRACJI GOSPODARCZEJ
}

\begin{abstract}
WSTĘP
Efektem procesu globalnej integracji gospodarczej jest rozwój regulacyjnych systemów, umożliwiających sprawne funkcjonowanie sieci powiązań ekonomicznych. Wzrost liczby gospodarczych interakcji spowodowanych procesami globalizacji powoduje m.in. narastanie liczby sporów. Możliwości ich rozwiązywania daje sprawnie funkcjonujacy system prawny. W wyniku wprowadzenia polityki „otwartych drzwi” oraz przystąpienia do WTO w roku 1999 Chiny uczyniły ogromny krok w kierunku integracji swojej gospodarki oraz systemu prawnego z systemami państw zachodnich.

Uzasadnieniem wzrostu popularności arbitrażu w Chinach jest nie tylko integracja gospodarcza Państwa Środka jako efekt postępującej globalizacji, ale także względy filozoficzno-kulturowe ${ }^{1}$. Chiński system prawny wykształcił się m.in. dzięki wpływom takich filozofii, jak: konfucjanizm, daoizm i legalizm². Konfucjanizm nawiązuje do norm społecznych i moralnych, natomiast konkurujaccy z nim legalizm podkreśla prymat prawa stanowionego. W konfucjanizmie istotna rolę odgrywa hierarchiczne utrzymanie struktury społeczeństwa oraz ogólu stosunków społecznych. Respektowanie praw i porządków powinno być z tej perspektywy normą społeczną. Konfucjusz wskazywał, że sytuacją idealną byłoby istnienie społeczeństwa wiernego porządkowi, hierarchii i harmonii, tak aby prawo stanowione było w zasadzie zbędne ${ }^{3}$.
\end{abstract}

1 Z. Xiuwen, L.A. Kloppenberg, Reforming Chinese arbitration law and practices in the global economy, University of Dayton, „Law Review” 2006, vol. 31, No. 3, s. 421.

2 J.M.Zimmerman, China Law Deskbook: A Legal Guide for Foreign-Invested Enterprises International, Aba Section of International Law, 2nd Edition, 2010, s. 31.

3 R.F. Utter, Dispute resolution in China, „Washington Law Review” 1987, vol. 62, No. 3, s. 162 . 
Celem artykułu jest prezentacja uwarunkowań i zasad funkcjonowania chińskiego systemu arbitrażowego oraz wskazanie jego cech charakterystycznych. Szczególną uwagę poświęca się arbitrażowi międzynarodowemu w Chinach. W związku z coraz większą ilością interakcji ekonomicznych z chińskimi podmiotami gospodarczymi wiedza na temat funkcjonowania dostępnych rozwiązań prawnych pozwoli zwiększyć sprawność podejmowanych decyzji gospodarczych w ChRL.

\section{ROZWÓJ SYSTEMU ARBITRAŻU W CHIŃSKIEJ REPUBLICE LUDOWEJ JAKO ALTERNATYWNEJ METODY ROZWIĄZYWANIA SPORÓW}

Przyjmuje się, że w ChRL istnieją cztery sposoby rozwiązywania sporów. Są to: negocjacje, mediacje, arbitraż oraz postępowanie sądowe. Arbitraż jest jedną z form alternatywnego rozwiązywania sporów. Lech Morawski pisze, że alternatywne metody rozwiązywania sporów w szerokim ujęciu obejmują katalog wszelkich typów działalności, mającej na celu minimalizowanie możliwości powstania sporu ${ }^{4}$. Rafał Morek wskazuje, że pojęcie to oznacza: „szereg różnych metod, służących rozwiązywaniu sporu dzięki pomocy neutralnego i bezstronnego podmiotu trzeciego, będących alternatywą dla możliwości rozstrzygania tego sporu przed sądem powszechnym" ${ }^{\prime}$. Z kolei zdaniem Andrzeja Wacha przez pojęcie alternatywnych metod rozwiązywania sporów należy rozumieć wszystkie pozasądowe formy rozwiązywania sporów prawnych, alternatywne wobec postępowania cywilnego, które są realizowane w każdym przypadku poza ramami sądownictwa państwowego ${ }^{6}$. Arbitraż z kolei według Witolda Broniewicza „oznacza rozpoznawanie sporów przez sąd polubowny" ${ }^{\prime}$. Andrzej Tynel definiuje sąd polubowny jako sąd niepaństwowy, powołany zgodną wolą stron do rozstrzygnięcia ich sporu wyrokiem, mającym moc prawną na równi z wyrokiem sądu państwowego" ${ }^{8}$. Generalnie do alternatywnych metod rozwiązywania sporów prócz arbitrażu zalicza się także negocjacje i mediacje. Postępowanie arbitrażowe w Chinach jest niezależne i wolne od wpływów organów władzy wykonawczej, jakichkolwiek insty-

4 L. Morawski, Proces sadowy a instytucje alternatywne (na przyktadzie sporów cywilnych), „Państwo i Prawo"1993, s. 12.

5 R. Morek, ADR - Alternatywne metody rozwiązywania sporów w sprawach gospodarczych, Wyd. C.H. Beck, Warszawa 2004, s. 1.

6 A. Wach, Alternatywne formy rozwiqzywania sporów sportowych, Liber, Warszawa 200, s. 124.

W. Broniewicz, Postepowanie cywilne w zarysie, Warszawa 1999, s. 392.

8 A. Tynel, Międzynarodowy arbitraż handlowy w krajach Europy Środkowej, Difin, Warszawa 1999, s. 15. 
tucji czy osób fizycznych. Orzeczenia arbitrażowe wydane zgodnie z prawem są uważane za ostateczne i wykonywane przez sądy powszechne9.

$\mathrm{Na}$ ukształtowanie chińskiego prawa arbitrażu wpływ miała ustawa wzorcowa o międzynarodowym arbitrażu handlowym. Stało się tak ze względu na konieczność zbliżenia regulacji chińskich do praktyki międzynarodowej. Podstawowym aktem prawnym, regulującym zagadnienia arbitrażu w Chinach jest Prawo arbitrażu Chińskiej Republiki Ludowej. Akt ten został uchwalony 31 sierpnia 1994 r. i wszedł w życie 1 września 1995 r. Innymi ważnymi aktami normatywnymi regulującymi kwestie związane $\mathrm{z}$ arbitrażem w Chinach, jest Prawo postępowania cywilnego ChRL z 1991 r. oraz interpretacja tego aktu dokonana przez Sąd Najwyższy z 1992 r. $^{10}$ Prawo arbitrażu jest zunifikowanym aktem, regulującym zarówno zagadnienia arbitrażu krajowego jak i arbitrażu zagranicznego, tak zwanego arbitrażu $z$ elementem obcym ${ }^{11}$. Ustawa wzorcowa UNCITRAL zawiera uniwersalną definicję arbitrażu międzynarodowego, jednak w chińskim Prawie arbitrażu przymiotnik „międzynarodowy” zastępuje się określeniem „z elementem obcym”. Wyjaśnienie przedmiotowego określenia znajdujemy w art. 304 Opinii Sądu Najwyższego dotyczącej implementacji prawa postępowania cywilnego, który stanowi, że termin „z elementem obcym” może odnosić się do następujących okoliczności:

a) kiedy obie bądź jedna ze stron mają inną (w tym przypadku inną niż chińska) narodowość lub są bezpaństwowcami, a w przypadku osoby prawnej lub organizacji gdy mają siedzibę w innym państwie,

b) kiedy zdarzenia prawne, które powodują zmianę lub zakończenie prawnych stosunków pomiędzy stronami, wydarzyły się w innym państwie,

c) kiedy przedmiot sporu położony jest w innym państwie ${ }^{12}$.

Chiński system arbitrażowy przewiduje trzy typy arbitrażu: arbitraż sporów wynikających $z$ umów i prawa własności, arbitraż sporów wynikających z prawa pracy (na mocy Prawa arbitrażu poddany odrębnym przepisom) oraz arbitraż sporów wynikłych $\mathrm{z}$ rolnictwa (również na mocy Prawa arbitrażu poddany odrębnym regulacjom). $Z$ punktu widzenia obecnie obowiązującego Prawa arbitrażu jakikolwiek inny typ arbitrażu nie jest dozwolony. Zgodnie z powyższym poddane pod arbitraż nie mogą zostać:

9 J. Chen, S. Ke, China Business Law Guide, vol. 2, first edition, Kluwer Law International, Hague 2005, s. 42.

10 A. Fiłoniuk, Kierunek wschód: arbitraż w Chinach, „Biuletyn Arbitrażowy” 2008, nr 5, s. 47.

11 S. Oraniec, J.J. Skoczylas, Pozasądowe rozwiazywanie sporów handlowych w CHRL, „Biuletyn Arbitrażowy" 2008, nr 10, s. 64; J. S. Mo, Arbitration Law in China, Sweet \& Maxwell Asia 2001, 43-43.

12 Art. 304 of Several Opinions of the Supreme People's Court Concerning the Implementation of the Civil Procedure Law, issued by the Supreme People's Court on and effective from 14.07.1992 r. 
a) spory dotyczące spraw małżeńskich, adopcji, opieki, alimentów i dziedziczenia

b) spory administracyjne, należące do kompetencji odpowiednich organów administracyjnych

Postępowania arbitrażowe w Chinach prowadzone są przez odpowiednie komisje arbitrażowe, będące członkami Chińskiego Stowarzyszenia Arbitrażowego (China Arbitration Association), którego podstawowym zadaniem jest nadzorowanie tych komisji. W Chinach funkcjonują komisje arbitrażowe CIETAC oraz CMAC, specjalizujące się przede wszystkim w rozwiązywaniu sporów z elementem obcym oraz lokalne komisje arbitrażowe rozlokowane w wybranych chińskich miastach ${ }^{13}$. Komisja arbitrażowa CIETAC powołana została do życia z dniem 2 kwietnia 1956 r. pod nazwą Foreign Trade Arbitration Commission of the China Council for the Promotion of International Trade. Główną siedzibą tej najbardziej znanej komisji w Chinach jest Pekin. W jej ramach funkcjonują podkomisje w Szanghaju, w Shenzhen oraz w Tianjinie, znane jako: CIETAC Shanghai Sub-Commission, CIETAC South China Sub-Commission i CIETAC Financial Arbitration Center w Tianjinie. Dodatkowo działalność prowadzi także 21 biur w ulokowanych różnych regionach Chin. Jurysdykcji CIETAC podlegają spory handlowe z elementem obcym, spory związane ze Specjalnym Regionem Administracyjnym Honkong, Specjalnym Regionem Administracyjnym Macao oraz regionem Tajwan, a także od 2000 r. spory krajowe ${ }^{14}$. Komisja CIETAC oferuje również rozstrzyganie sporów online, powstałych na polu handlu elektronicznego ${ }^{15}$. Od tego też roku przedmiotowa komisja nazywana jest również Sądem Arbitrażowym Chińskiej Izby Handlu Międzynarodowego (China Council for the Promotion of International Trade) ${ }^{16}$. W pierwszym dziesięcioleciu funkcjonowania, tj. w latach 1956-1966 CIETAC przyjęła do rozpatrzenia 20 spraw. Dla porównania warto wskazać, że w roku 2008 komisja ta rozstrzygnęła 1097 spraw. W tabeli 1 przedstawiono sprawy rozstrzygnięte przez CIETAC w latach 1990-2008.

Tabela 1. Sprawy rozstrzygnięte przez CIETAC w latach 1990-2008

\begin{tabular}{|c|c|c|c|c|c|}
\hline Rok & $\begin{array}{c}\text { Komisja } \\
\text { W Pekinie }\end{array}$ & $\begin{array}{c}\text { Podkomisja } \\
\text { w Szanghaju }\end{array}$ & $\begin{array}{c}\text { Podkomisja } \\
\text { w Shenzhen }\end{array}$ & $\begin{array}{c}\text { Podkomisja } \\
\text { w Tianjinie }\end{array}$ & $\begin{array}{c}\text { Całkowita } \\
\text { liczba spraw }\end{array}$ \\
\hline 2008 & 561 & 366 & 170 & - & 1097 \\
\hline
\end{tabular}

\footnotetext{
J.S. Mo, op. cit., s. 118.

J. Chen, S. Ke, op. cit., s. 43,001.

http://www.cietac.org/index.cms

$16 \mathrm{http} / /$ www.sccietac.org/cietac/en/introduce/index.jsp
} 
cd. tab. 1

\begin{tabular}{|c|c|c|c|c|c|}
\hline Rok & $\begin{array}{c}\text { Komisja } \\
\text { w Pekinie }\end{array}$ & $\begin{array}{l}\text { Podkomisja } \\
\text { w Szanghaju }\end{array}$ & $\begin{array}{l}\text { Podkomisja } \\
\text { w Shenzhen }\end{array}$ & $\begin{array}{l}\text { Podkomisja } \\
\text { w Tianjinie }\end{array}$ & $\begin{array}{l}\text { Całkowita } \\
\text { liczba spraw }\end{array}$ \\
\hline 2007 & 582 & 292 & 177 & - & 1051 \\
\hline 2006 & 481 & 315 & 171 & - & 967 \\
\hline 2005 & 449 & 301 & 209 & - & 958 \\
\hline 2004 & 379 & 180 & 141 & - & 700 \\
\hline 2003 & 390 & 206 & 108 & - & 704 \\
\hline 2002 & 408 & 175 & 111 & - & 694 \\
\hline 2001 & 429 & 147 & 136 & - & 712 \\
\hline 2000 & 493 & 127 & 118 & - & 738 \\
\hline 1999 & 459 & 120 & 127 & - & 738 \\
\hline 1998 & 508 & 110 & 118 & - & 736 \\
\hline 1997 & 560 & 85 & 121 & - & 766 \\
\hline 1996 & 569 & 77 & 151 & - & 797 \\
\hline 1995 & 628 & 89 & 158 & - & 875 \\
\hline 1994 & 430 & 87 & 57 & - & 574 \\
\hline 1993 & 217 & 21 & 56 & - & 294 \\
\hline 1992 & - & - & - & - & 236 \\
\hline 1991 & - & - & - & - & 205 \\
\hline 1990 & - & - & - & - & 203 \\
\hline
\end{tabular}

Źródło: http://www.cietac.org/index.cms.

Analizując bieżące zmiany Regulaminu CIETAC, stwierdza się, że rewizje odzwierciedlają dwa trendy: pierwszy z nich to dążenie do zbieżności z praktyką międzynarodową, drugi to zwiększanie autonomii i swobody dla stron ${ }^{17}$. Inną znaną komisją arbitrażową w Chinach jest CMAC, powołana do życia 1 maja 1959, pod nazwą Maritime Arbitration Commission, z siedzibą w Pekinie ${ }^{18}$. Jest to komisja arbitrażowa rozstrzygająca spory morskie. Od 1982 r. komisja funkcjonuje pod nazwą China Maritime Arbitration Commission. Regulamin

17 R. Peerenboom, X. He, Dispute Resolution in China: Patterns, Causes, and Prognosis. „East Asia Law Review”2009, 4(1), 1-61, s. 29.

18 J. Chen, S. Ke, op. cit., s. 43, 201. 
CMAC został wprowadzony i nowelizowany, aby zbliżyć chiński arbitraż morski do praktyki międzynarodowej ${ }^{19}$. W ramach CMAC utworzono jedną podkomisję z siedzibą w Szanghaju oraz kilka współpracujących biur. Arbitrzy CMAC są powoływani spośród profesjonalistów o specjalistycznej wiedzy oraz praktycznym doświadczeniu w nawigacji, ubezpieczeniach, prawie morskim oraz w wielu innych dziedzinach ${ }^{20}$.

\section{UMOWA O ARBITRAŻ ORAZ UWARUNKOWANIA FUNKCJONOWANIA ARBITRÓW W ARBITRAŻU MIĘDZYNARODOWYM W CHRL}

Strony przyjmujące arbitraż dla rozstrzygnięcia sporów powinny zawrzeć wzajemną i dobrowolną umowę, w przypadku braku porozumienia o arbitraż, komisja arbitrażowa nie przyjmie bowiem wniosku o przeprowadzenie postępowania arbitrażowego zgłoszonego przez jedną ze stron. Należy mieć na uwadze, że w każdym postępowaniu arbitrażowym właściwość odpowiedniej instytucji arbitrażowej jest oparta na istnieniu ważnego zapisu na sąd polubowny. Umowa o arbitraż powinna być stwierdzona pismem ${ }^{21}$. Na mocy Prawa arbitrażu możemy wyróżnić dwa rodzaje umów arbitrażowych, a mianowicie klauzulę arbitrażową zawartą $\mathrm{w}$ kontrakcie głównym oraz odrębną umowę w przedmiocie poddania sporu pod arbitraż. W praktyce zdecydowanie dominuje pierwsza ze wskazanych form. Jednakże drugi rodzaj umowy daje stronom możliwość poddania pod arbitraż sporu powstałego przed zawarciem umowy oraz usunięcia ewentualnej wadliwości, którą może być dotknięty uprzednio zawarty zapis na sąd polubowny ${ }^{22}$. Stroną umowy o arbitraż mogą być osoba fizyczna, osoba prawna oraz inne organizacje jako równe względem prawa podmioty.

W Chinach właściwymi do weryfikacji ważności zapisu na sąd polubowny są zarówno komisje arbitrażowe, jak i sądy powszechne. Sprawdzenie ważności umowy o arbitraż przez komisję arbitrażową stanowi część procesu arbitrażowego. Natomiast w przypadku sądów mogą one tego dokonać w ramach dwóch oddzielnych procedur. Jedną z nich jest sprawdzenie ważności umowy o arbitraż na wniosek strony tej umowy. Druga z procedur może zostać uruchomiona w przypadku rozpatrywania wniosku o uchylenie orzeczenia arbitrażowego.

\footnotetext{
J. Tao, Arbitration Law and Practice in China, 2nd ed., Kluwer Law Intl. 2008, s. 19.

http://www.cmac-sh.org/en/organization.asp.

J. Tao, op. cit., s. 34.

J. Chen, S. Ke, op. cit., s. 42, 503.
} 
Jeśli strony kwestionują ważność zapisu na sąd polubowny, to wszelkie obiekcje powinny zostać zgłoszone przed rozpoczęciem pierwszej rozprawy przed trybunałem arbitrażowym. W Chinach ustanowiony został system ostatecznego określania, który stanowi, że w przypadku wniosków składanych przez obcokrajowców, kiedy sądy niższego rzędu orzekają o nieważności umowy arbitrażowej, przedkładają swoje rozstrzygnięcie Sądowi Apelacyjnemu w celu ich zatwierdzenia. System ten znajduje również zastosowanie, gdy sąd odmawia uznania wykonania zagranicznego orzeczenia arbitrażowego. Umowa arbitrażowa jest nieważna w razie zaistnienia jednej z poniższych okoliczności:

a) zakres materii będącej przedmiotem arbitrażu przekracza zakres wskazany prawem,

b) jedna ze stron umowy arbitrażowej nie ma zdolności do czynności prawnych bądź ma ograniczoną zdolność do czynności prawnych,

c) jedna ze stron doprowadziła drugą ze stron do zawarcia umowy arbitrażowej, stosując w stosunku do niej przymus.

Ponadto, stosownie do postanowień Prawa arbitrażu, jeśli w umowie arbitrażowej strony nie uzgodniły zakresu materii arbitrażu, instytucji arbitrażowej lub jeśli postanowienia te są niejasne, strony mogą uzupełnić swoją umowę. Jeżeli strony nie zawrą umowy uzupełniającej, umowa o arbitraż będzie nieważna.

Chińskie Prawo arbitrażu zawiera odrębną regulację w przedmiocie wymagań stawianych arbitrom $\mathrm{w}$ przypadku arbitrażu krajowego i arbitrażu z elementem obcym. Aktualnie obowiązujące Prawo Arbitrażu wymaga, aby każda komisja arbitrażowa sporządziła listę arbitrów według różnych zawodów. W dniu 13 lipca 2006 r. Najwyższy Sąd Ludowy wydał uwagę, zgodnie z którą sędziowie aktywni zawodowo nie mogą pełnić funkcji arbitrów w żadnym postępowaniu arbitrażo$w_{y m}{ }^{23}$. W Chinach w ramach arbitrażu krajowego konieczne jest, aby arbitrem była osoba narodowości chińskiej. W związku z powyższym CIETAC sporządziła dwie odrębne listy arbitrów: listę arbitrów dla spraw krajowych oraz listę arbitrów dla spraw międzynarodowych. Dnia 1 września 1995 r. CIETAC oraz CMAC łącznie przyjęły akt prawny (CIETAC and CMAC Stipulations for Appointment of Arbitrators) stanowiący o wymaganiach warunkujących dopuszczalność powołania na arbitra. Generalnie ujmując, arbiter powinien być sprawiedliwy, niezależny, bezstronny, posiadać wiedzę w zakresie prawa, ekonomii, handlu, technologii lub spraw morskich oraz posiadać określone doświadczenie zawodowe.

Trybunał arbitrażowy może składać się z jednego bądź trzech arbitrów. Jeśli strony uzgodnią, aby trybunał arbitrażowy składał się z trzech arbitrów, wtedy

23 The People's Supreme Court Notice on the Withdraw of Judges in Active Duty from their Duty as Arbitrators in Various Arbitration Commission, July 132004 r., Z. Xiuwen, International Commercial Arbitration Law 196 (Renmin U. Press 2004). 
każda ze stron wybiera jednego arbitra lub upoważnia przewodniczącego komisji arbitrażowej, aby ten powołał arbitra. Natomiast trzeci arbiter zostanie wybrany wspólnie przez strony lub będzie powołany przez przewodniczącego komisji arbitrażowej, zgodnie $\mathrm{z}$ udzielonym mu przez strony upoważnieniem. Trzeci arbiter będzie przewodniczącym trybunału. Jeśli natomiast strony uzgodniły jednoosobowy skład, arbiter powinien zostać wybrany wspólnie przez obie strony bądź powołany przez przewodniczącego komisji arbitrażowej zgodnie z upoważnieniem stron. Jeśli jednak strony $\mathrm{w}$ terminie wskazanym w regulaminie arbitrażowym nie dokonają wyboru sposobu powołania arbitrów bądź nie wybiorą arbitrów, arbitrzy zostaną powołani przez przewodniczącego komisji arbitrażowej.

Prawo arbitrażu zawiera wyliczenie okoliczności, ze względu na które arbiter podlega wyłączeniu od prowadzenia sprawy, m.in. jest stroną albo bliskim krewnym strony bądź jej pełnomocnika, jest związany ze sprawą, pozostaje w innym stosunku ze stroną postępowania bądź jej pełnomocnikiem, co mogłoby oddziaływać na bezstronność arbitra. Jeśli któraś ze stron uważa, że zaistniała okoliczność stanowiąca podstawę wyłączenia arbitra, to powinna złożyć stosowny wniosek o wyłączenie przed pierwszą rozprawą i wskazać powody uzasadniające wyłączenie. Jeśli natomiast strona dowiedziała się o przyczynach uzasadniających wyłączenie arbitra dopiero po rozpoczęciu pierwszej rozprawy, może ona złożyć wniosek o jego wyłączenie, nie później jednak niż do zakończenia ostatniej rozprawy. Prawo arbitrażu stanowi, że o wyłączeniu arbitra decyduje przewodniczący komisji arbitrażowej. W przypadku gdy przewodniczący komisji pełni funkcje arbitra, o wyłączeniu arbitra decyduje kolegialnie komisja arbitrażowa. Gdy arbiter zostanie skutecznie wyłączony lub gdy nie może pełnić swoich obowiązków $\mathrm{z}$ innych powodów, na jego miejsce zostanie wybrany lub powołany inny arbiter, według procedury opisanej powyżej. W takim przypadku strony mogą wnieść o ponowne rozpoczęcie postępowania arbitrażowego, jednak ostateczna decyzja w tym względzie należy do trybunału arbitrażowego. Ponadto trybunał arbitrażowy sam może podjąć decyzję w przedmiocie rozpoczęcia od nowa postępowania arbitrażowego.

\section{POSTĘPOWANIE ARBITRAŻOWE W CHINACH}

Jeśli strony nie uregulują kwestii miejsca arbitrażu, będzie nim siedziba wybranej przez strony komisji arbitrażowej. Strony mogą uzgodnić język, w którym prowadzone będzie postępowanie. W braku stosownego porozumienia językiem oficjalnym postępowania jest język chiński. Strony oraz ich prawni przedstawiciele mogą ustanawiać profesjonalnych pełnomocników. Postępowanie arbitrażowe może zostać wszczęte wyłącznie na pisemny wniosek strony. Konieczny- 
mi przesłankami wystąpienia $\mathrm{z}$ wnioskiem o arbitraż przez strony są: istnienie umowy o arbitraż, którą to strony są obowiązane przedłożyć komisji, roszczenia oraz okoliczności faktyczne, uzasadniające roszczenie. Ponadto dana sprawa musi należeć do właściwości danej komisji arbitrażowej. Wniosek o arbitraż musi jasno określać dane stron, żądanie, okoliczności faktyczne, na których oparto żądanie, oraz dowody na poparcie wniosku. Wniosek składa się wraz z dokonaniem opłaty arbitrażowej zgodnie $\mathrm{z}$ taryfą opłat. W tabeli 2 przedstawiono taryfikator opłat, które należy uiścić w przypadku zaistnienia sporu z elementem obcym.

Tabela 2. Taryfikator opłat w przypadku spraw z elementem obcym

\begin{tabular}{|c|c|}
\hline WARTOŚĆ PRZEDMIOTU SPORU (RMB) & Wysokośc OPŁATY (RMB) \\
\hline Do 1000000 & 3,5\% wartości przedmiotu sporu, minimum 10000 RMB \\
\hline 1000000 do 5000000 & 35000 RMB plus 2,5\% od kwoty powyżej 1000000 RMB \\
\hline 5000000 do 10000000 & 135000 RMB plus 1,5\% od kwoty powyżej 5000000 RMB \\
\hline 10000000 do 50000000 & 210000 RMB plus $1 \%$ od kwoty powyżej 10000000 RMB \\
\hline 50000000 i więcej & 610000 RMB plus $0,5 \%$ od kwoty powyżej 50000000 RMB \\
\hline
\end{tabular}

* Arbitration Fee Schedule for International or Foreign- related Cases, http://www.cietac.org/index.cms Źródło: http://www.cietac.org/index.cms.

Stosownie do obwieszczenia Rady Państwa na opłaty arbitrażowe w przypadku arbitrażu krajowego składają się: opłata rejestracyjna oraz opłata manipulacyjna. W tabeli 3 przedstawia się wysokość opłat rejestracyjnej i manipulacyjnej w przypadku postępowań arbitrażu krajowego.

Tabela 3. Wysokość opłat rejestracyjnej i manipulacyjnej w przypadku postępowań arbitrażu krajowego

\begin{tabular}{|c|c|c|}
\hline WARTOŚĆ PRZEDMIOTU SPORU (RMB) & Wysokośc OPtATY (RMB) & WySOKOŚC OPLATY MANPULLAYYNEJ (RMB) \\
\hline Do 1000 & $\begin{array}{l}3,5 \% \text { wartości przedmiotu sporu, } \\
\text { minimum } 100 \text { RMB }\end{array}$ & \multirow{2}{*}{ Minimum 1250 RMB } \\
\hline 1001 do 50000 & 100 RMB plus 5\% kwoty powyżej 1000 RMB & \\
\hline 50001 do 100000 & 2550 RMB plus 4\% kwoty powyżej 50000 RMB & \multirow{2}{*}{$\begin{array}{l}1250 \text { RMB plus 2,5\% kwoty } \\
\text { powyżej } 50000\end{array}$} \\
\hline 100001 do 200000 & 4550 RMB plus 3\% kwoty powyżej 100000 RMB & \\
\hline
\end{tabular}


cd. tab. 3

\begin{tabular}{|c|c|c|}
\hline WARTOŚĆ PRZEDMIOTU SPORU (RMB) & WYSOKOŚC OPLATY (RMB) & Wysokość OPŁATY MANPULACYJNEJ (RMB) \\
\hline 200001 do 500000 & 7550 RMB plus 2\% kwoty powyżej 200000 RMB & $\begin{array}{l}5000 \text { RMB plus } 2 \% \text { kwoty } \\
\text { powyżej } 200000\end{array}$ \\
\hline 500001 do 1000000 & 13550 RMB plus 1\% kwoty powyżej 500000 RMB & $\begin{array}{l}11000 \text { RMB plus 1,5\% kwoty } \\
\text { powyżej } 500000\end{array}$ \\
\hline 1000001 do 3000000 & \multirow[t]{6}{*}{$\begin{array}{l}18550 \text { RMB plus 0,5\% kwoty powyżej } \\
1000000 \text { RMB }\end{array}$} & $\begin{array}{l}18500 \text { RMB plus } 0,5 \% \text { kwoty } \\
\text { powyżej } 1000000\end{array}$ \\
\hline 3000000 do 6000000 & & $\begin{array}{l}28500 \text { RMB plus } 0,45 \% \text { kwoty } \\
\text { powyżej } 3000000\end{array}$ \\
\hline 6000000 do 10000000 & & $\begin{array}{l}42000 \text { RMB plus } 0,4 \% \text { kwoty } \\
\text { powyżej } 6000000\end{array}$ \\
\hline 10000000 do 20000000 & & $\begin{array}{l}58000 \text { RMB plus } 0,3 \% \text { kwoty } \\
\text { powyżej } 10000000\end{array}$ \\
\hline 20000000 do 40000000 & & $\begin{array}{l}88000 \text { RMB plus } 0,2 \% \text { kwoty } \\
\text { powyżej } 20000000\end{array}$ \\
\hline 40000000 i więcej & & $\begin{array}{l}128000 \text { RMB plus } 0,15 \% \text { kwoty } \\
\text { powyżej } 40000000\end{array}$ \\
\hline
\end{tabular}

Źródło: jak w tab. 2.

Zasadą jest, że trybunał arbitrażowy przeprowadza rozprawę w celu rozpoznania sprawy. Jednakże, jeśli strony są zgodne w przedmiocie nieprzeprowadzania rozprawy, trybunał arbitrażowy może wydać orzeczenie arbitrażowe na podstawie wniosku o arbitraż, przedstawionego stanowiska strony pozwanej oraz innych dokumentów. Przyjąć więc należy, że rozprawa nie jest koniecznym elementem postępowania arbitrażowego w Chinach. Kolejną zasadą jest niejawność przeprowadzanej rozprawy. Niemniej jednak, w razie odmiennej woli stron, trybunał arbitrażowy może $\mathrm{z}$ reguły procedować podczas jawnej rozprawy. Terminy rozpraw, zarówno tych odbywanych z udziałem stron, jak i posiedzeń bez ich udziału, określa komisja arbitrażowa. Komisja arbitrażowa powiadamia każdą ze stron o wyznaczonym terminie rozprawy. Jeśli powód nie stawi się na wyznaczonej rozprawie w terminie, o którym został poinformowany na piśmie, bez podania uzasadnionych przyczyn lub opuści salę podczas rozprawy bez uzyskania pozwolenia trybunału arbitrażowego, złożony przez niego wniosek o arbitraż zostanie uznany za cofnięty. Regulamin CIETAC stanowi ponadto, że w takim przypadku, jeśli pozwany dochodzi roszczenia wzajemnego, trybunał arbitrażowy przeprowadzi rozprawę w tym względzie i wyda wyrok zaoczny. Jeśli pozwany bez uzasadnienia nie stawi się na rozprawie w terminie, o którym został poinformowany na 
piśmie, lub oddali się z sali podczas rozprawy bez zgody trybunału arbitrażowego, trybunał jest uprawniony do wydania wyroku zaocznego. Jeśli pozwany dochodził jednocześnie roszczenia wzajemnego, można uważać, że cofnął on swój wniosek.

Prawo arbitrażu stanowi, że strony przedstawiają dowody na poparcie swoich roszczeń, nie określa ono jednak bezpośrednio znaczenia dowodu w postępowaniu arbitrażowym. Mimo że postępowanie arbitrażowe nie jest tożsame z postępowaniem cywilnym, to jednak wskazuje się, że odpowiednie formy dowodów w ramach arbitrażu powinny być zdeterminowane przez odniesienie do art. 63 prawa postępowania cywilnego. Artykuł 63 chińskiego prawa postępowania cywilnego zawiera enumeratywne wyliczenie następujących kategorii dowodów: dowód $\mathrm{z}$ dokumentu, dowód rzeczowy, materiały audiowizualne, zeznania świadków, przesłuchanie stron, dowód z opinii biegłego, protokoły z dochodzenia sądowego. Na stronach spoczywa ciężar dowodowy, gdyż na początku rozprawy muszą przedstawić dowody na poparcie swoich twierdzeń. Każda ze stron może kwestionować ważność dowodów przedstawionych przez stronę przeciwną. $\mathrm{Na}$ leży zauważyć, że na mocy Prawa arbitrażu, trybunał arbitrażowy - jeśli uzna, iż istnieje taka potrzeba - może gromadzić dowody z urzędu. Jest to istotna cecha postępowania arbitrażowego w Chinach, gdyż oznacza, że trybunał arbitrażowy może odgrywać aktywną rolę w rozwiązywaniu sporu w ramach arbitrażu ${ }^{24}$. Dowody powinny być przeprowadzane na rozprawie. Aby dany dowód mógł zostać wzięty pod uwagę, musi zostać przedstawiony.

\section{WYDANIE I WYKONYWANIE ORZECZEŃ W CHIŃSKIM SYSTEMIE ARBITRAŻOWYM}

Wydanie orzeczenia arbitrażowego jest ostatnim etapem postępowania arbitrażowego. Orzeczenie arbitrażowe jest ostateczne i wiążące ${ }^{25}$. W przypadku arbitrażu międzynarodowego, według postanowień regulaminu CIETAC, orzeczenie powinno zostać wydane w ciągu sześciu miesięcy od uformowania trybunału. Jeśli chodzi o postępowanie arbitrażowe, prowadzone w ramach arbitrażu krajowego, to musi się ono zakończyć w ciągu czterech miesięcy od ukonstytuowania składu trybunału. Jeszcze krótszym terminem związany jest trybunał w przypadku procedury skróconej, musi bowiem wydać orzeczenie nie później niż przed upływem trzech miesięcy od uformowania trybunału. W każdym z powyżej wskazanych przypadków przewodniczący CIETAC, na wniosek trybunału arbitrażowego, może przedłużyć termin na wydanie orzeczenia, jeśli uzna, że jest to konieczne,

24 J. S. Mo, op. cit., s. 218.

25 Ibidem, s. 275. 
a powody przedłużenia są uzasadnione. Według art. 53 Prawa arbitrażu wyrok arbitrażowy zapada większością głosów. Arbiter może zgłosić zdanie odrębne. W razie równości głosów za i przeciw decydujące znaczenie ma głos arbitra przewodniczącego. Wyrok arbitrażowy staje się prawnie wiążący z dniem jego wydania. Strony powinny wykonać wyrok dobrowolnie w terminie zakreślonym w wydanym orzeczeniu. W razie braku określenia przedmiotowego terminu strony powinny wykonać wyrok niezwłocznie. Jeśli jedna ze stron nie wykona wyroku, druga może wystąpić do właściwego chińskiego sądu o wykonanie wyroku według prawa chińskiego lub wystąpić do odpowiedniego sądu o wykonanie wyroku według konwencji nowojorskiej lub innych międzynarodowych traktatów, które Chiny zawarły lub do których przystąpiły.

Strony mogą wnieść do sądu okręgowego miejsca siedziby komisji arbitrażowej o uchylenie orzeczenia arbitrażowego, jeśli udowodnią, że zaistniała któraś z okoliczności uregulowanych przepisami prawa. Uchylenie wyroku arbitrażowego mieści się w ramach sądowej kontroli, przez którą sąd ludowy kontroluje i bada czynności podjęte przez trybunał oraz zachowania arbitrów, w celu zapewnienia bezstronności, niezależności oraz słuszności orzeczenia arbitrażowego ${ }^{26}$. Sądowa kontrola orzeczeń arbitrażowych jest dopuszczalna tylko w ściśle określonych przypadkach $^{27}$. Prawo arbitrażu w art. 59 zakreśla sześciomiesięczny termin biegnący od dnia doręczenia wyroku, w którym strony mogą wystąpić z wnioskiem o uchylenie orzeczenia. W przypadku orzeczenia wydanego na skutek postępowania arbitrażowego z elementem obcym sąd może rozpoznać sprawę jedynie co do kwestii proceduralnych. W przypadku orzeczeń krajowych sąd może skupić się na badaniu istoty sprawy ${ }^{28}$.

Wykonalność orzeczeń arbitrażowych stanowi podstawową różnicę pomiędzy arbitrażem oraz innymi pozasądowymi sposobami rozwiązywania sporów ${ }^{29}$. Sposób ich wykonywania zależy od rodzaju orzeczenia arbitrażowego, a mianowicie od tego, czy jest to orzeczenie krajowe, czy też z elementem obcym. Jeśli jedna ze stron nie wykona wyroku, druga strona może wystąpić do sądu okręgowego (w przypadku arbitrażu krajowego właściwy rzeczowo jest sąd rejonowy) miejsca siedziby bądź zamieszkania drugiej strony lub miejsca położenia mienia tej osoby o jego wykonanie, zgodnie $\mathrm{z}$ odpowiednimi postanowieniami chińskiej procedu-

\footnotetext{
26 Ibidem, s. 369.

27 X Zhang, Arbitration in China: A Legal Overview, Murdoch University 1999, vol. 6, No. 3, s. 7.

28 Opinion on Some Issues Regarding the Determination of the Application for Ascertaining the Validity of an Arbitration Agreement and Motions to Revoke an Arbitration Award, Beijing Higher People's Court, 1999.

29 J.S. Mo, op. cit., s. 401.
} 
ry cywilnej ${ }^{30}$. Jeśli orzeczenie wydane przez organ arbitrażowy, mający siedzibę poza terytorium Chin, wymaga uznania i wykonania przez chiński sąd ludowy, strona zainteresowana powinna złożyć wniosek bezpośrednio do sądu okręgowego miejsca zamieszkania bądź siedziby drugiej strony, bądź miejsca lokalizacji mienia tej osoby. Sąd ludowy rozpatrzy sprawę zgodnie z międzynarodowymi traktatami zawartymi przez Chiny bądź traktatami, do których Chiny przystąpiły, lub na zasadzie wzajemności. Zgodnie $\mathrm{z}$ art. 219 prawa postępowania cywilnego w przypadku wyroków, których stronami są osoby fizyczne, mogą one wystąpić $\mathrm{z}$ wnioskiem o wykonanie wyroku w ciągu jednego roku liczonego od ostatniego dnia terminu wyznaczonego na wykonanie wyroku. Natomiast gdy obie strony są osobami prawnymi lub innymi organizacjami, wtedy termin do wniesienia o wykonanie wyroku upływa po sześciu miesiącach liczonych od ostatniego dnia terminu wyznaczonego na wykonanie wyroku.

Sąd odmówi wykonania wyroku arbitrażowego, jeśli strona, przeciwko której wniesiono o wykonanie wyroku, udowodni, że jest on dotknięty jedną z wad określonych prawem, a zbliżoną do okoliczności uzasadniających uchylenie orzeczenia arbitrażowego. Sąd Najwyższy ma de jure moc stanowienia prawa, dlatego też jego oficjalna interpretacja prawa arbitrażowego jest prawnie wiążąca. W kwietniu 2005 r. Ludowy Sąd Najwyższy wydał ogłoszenie, ustanawiając system scentralizowanego raportowania i rewizji (system raportowania), obejmujący wszystkie sprawy, w których sąd okręgowy odmówił wykonania wyroku z elementem obcym oraz uznania i wykonania wyroku zagranicznego. System raportowania nałożył na sądy okręgowe obowiązek polegający na tym, że przed orzeczeniem o niewykonaniu lub nieuznaniu i niewykonaniu wskazanych powyżej orzeczeń muszą one złożyć sprawozdanie sądowi apelacyjnemu swojej właściwości w celu zbadania słuszności mającego zapaść rozstrzygnięcia. Jeśli sąd apelacyjny również zgadza się z ustaleniami, że należy odmówić uznania i wykonania lub wykonania danego orzeczenia, musi przedstawić swoje ustalenia Sądowi Najwyższemu. Jeśli Sąd Najwyższy potwierdzi poczynione ustalenia, sąd okręgowy może orzec o odmowie wykonania lub uznania i wykonania orzeczenia arbitrażowego ${ }^{31}$.

J. Tao, op. cit., s. 131.

Paragraph 2 of Centralized Report and Review System Notice of Supreme People's Court on Several Issues Regarding the Handling by the People's Court on Certain Issues Pertaining to Foreign Related Arbitration and Foreign Arbitration, issued by Supreme People's Court, effective from 28.04.1995. 


\section{CECHY CHARAKTERYSTYCZNE ARBITRAŻU CHIŃSKIEGO ORAZ WNIOSKI}

Mimo że chiński arbitraż jest podobny pod wieloma względami do systemów arbitrażowych $\mathrm{w}$ innych państwach, to jednak charakteryzuje się on pewnymi odmiennymi cechami, jak np. niedopuszczalnością arbitrażu ad hoc oraz ograniczeniami odnośnie do reprezentowania stron przez zagranicznych prawników. Artykuł 16 Prawa arbitrażu wskazuje, że jednym z obligatoryjnych elementów umowy arbitrażowej jest wskazanie wybranej przez strony komisji arbitrażowej. Charakterystyczną cechą chińskiego systemu arbitrażowego jest niedopuszczalność prowadzenia w Chinach arbitrażu przez zagraniczne instytucje arbitrażowe. Art. $16 \mathrm{w}$ powiązaniu $\mathrm{z}$ art. 10 Prawa arbitrażu wiąże pojęcie komisji arbitrażowej $\mathrm{z}$ instytucją chińską. W razie braku określenia w umowie właściwej komisji arbitrażowej zgodnie $\mathrm{z}$ art. 18 strony są uprawnione do jej uzupełnienia. Gdy strony nie uzupełnią umowy przez wskazanie odpowiedniej komisji, ich zapis na sąd polubowny będzie nieważny.

Analizując dane statystyczne oraz wielość zawieranych kontraktów i transakcji biznesowych pomiędzy podmiotami chińskimi i zagranicznymi, stwierdza się, że arbitraż będzie coraz bardziej popularną formą rozwiązywania sporów w Chinach. Zauważa się ponadto dynamiczny wzrost popularności arbitrażu komisji arbitrażowej CIETAC w Szanghaju. Powodem tego jest wzrost liczby biznesowych interakcji zawieranych w Delcie Rzeki Jangcy, jak i uznawane przez przedsiębiorców przyjazne otoczenie biznesu ${ }^{32}$.

Jak pokazują statystyki, większość sporów rozwiązywanych metodą arbitrażu w Chinach dotyczy spraw handlowych ${ }^{33}$. Pomimo dynamicznego rozwoju arbitraż jest w Chinach formą wciąż rzadko braną pod uwage przez przedsiębiorstwa małe i średnie. Dzieje się tak ze względu na koszty, m.in. koszty podróży, zaangażowania prawnika, procedury arbitrażowej ${ }^{34}$ oraz wciąż niską wiedzę przedsiębiorców w tym zakresie. Aktualnie wraz ze wzrostem importu towarów i usług przez ChRL, co związane jest także z wdrażanym od roku 2011 dwunastym planem 5-letnim i dynamicznym rozwojem inwestycji zagranicznych, istnieją przesłanki, by stwierdzić, że dynamika rozwoju arbitrażu w Chinach jeszcze przyspieszy.

32 European Business in China, „Asia-Pacific Headquarters Study”, European Chamber of Commerce in China, 2011.

33 http://www.cietac.org/index.cms.

34 Patrz tabela 2. 


\section{ZAKOŃCZENIE}

Przedstawione informacje na temat systemu arbitrażu w Chinach są uzasadnieniem wzrostu jego popularności w okresie hemisferycznej integracji gospodarczej. Pomimo to zauważa się brak dostatecznej wiedzy wśród wielu przedsiębiorców podejmujących działania na chińskim rynku na temat możliwości prawnych, jakie daje arbitraż międzynarodowy w Chinach. Pozyskanie tej wiedzy wpłynie m.in. na zwiększenie liczby umów zawierających odpowiednie zapisy na sąd polubowny. Wiedza i nabyte doświadczenia pozwolą na podniesienie sprawności podejmowanych działań gospodarczych w Chinach, ekonomiczny wzrost przedsiębiorstw, oraz wzrost ilościowy i jakościowy międzynarodowych więzi gospodarczych.

\section{BIBLIOGRAFIA}

Broniewicz W., Postępowanie cywilne w zarysie, Warszawa 1999.

Chen J. , Ke S., China Business Law Guide, vol. 2, first edition, Kluwer Law International, Hague 2005.

European Business in China, European Chamber of Commerce in China, „Asia-Pacific Headquarters Study" 2011.

Fiłoniuk A., Kierunek wschód: arbitraż w Chinach, „Biuletyn Arbitrażowy” 2008, nr 5.

Mo J.S., Arbitration Law in China, Sweet \& Maxwell Asia 2001.

Morawski L., Proces sq̨owy a instytucje alternatywne (na przyktadzie sporów cywilnych), „Państwo i Prawo” 1993.

Morek R., ADR - Alternatywne metody rozwiquzywanie sporów w sprawach gospodarczych, Wyd C.H. Beck, Warszawa 2004.

Oraniec S., Skoczylas J. J., Pozasqdowe rozwiqzzywanie sporów handlowych w CHRL, „Biuletyn Arbitrażowy" 2008, nr 10.

Peerenboom R., He X., Dispute Resolution in China: Patterns, Causes, and Prognosis. „East Asia Law Review" 2009, vol. 4(1), s. 1-61.

Tao J., Arbitration Law and Practice in China, 2nd ed., Kluwer Law Intl. 2008.

Tynel A., Międzynarodowy arbitraż handlowy w krajach Europy Środkowej, Difin, Warszawa 1999.

Utter R.F., Dispute resolution in China, „Washington Law Review” 1987, vol. 62, No. 3.

Wach A., Alternatywne formy rozwiazywania sporów sportowych, Liber, Warszawa 2005.

Xiuwen Z., Kloppenberg L.A., Reforming Chinese arbitration law and practices in the global economy, „University of Dayton Law Review” 2006, vol. 31, No. 3.

Zhang X., Arbitration in China: A Legal Overview. „Murdoch University” 1999, vol. 6, No. 3.

Zimmerman J.M., China Law Deskbook: A Legal Guide for Foreign-Invested Enterprises International, Aba Section of international Law, 2nd Edition, 2010. 
Centralized Report and Review System Notice of Supreme People's Court on Several Issues Regarding the Handling by the People's Court on Certain Issues Pertaining to Foreign Related Arbitration and Foreign Arbitration, issued by Supreme People's Court, effective from 28.04.1995.

Opinion on Some Issues Regarding the Determination of the Application for Ascertaining the Validity of an Arbitration Agreement and Motions to Revoke an Arbitration Award, Beijing Higher People's Court, 1999.

Several Opinions of the Supreme People's Court Concerning the Implementation of the Civil Procedure Law, issued by the Supreme People's Court on and effective from 14.07.1992.

The People's Supreme Court Notice on the Withdraw of Judges in Active Duty from their Duty as Arbitrators in Various Arbitration Commission, July 132004 r.; Z. Xiuwen, International Commercial Arbitration Law 196 (Renmin U. Press 2004). http://www.cietac.org/index.cms. http://www.sccietac.org/cietac/en/introduce/index.jsp.

\section{INTERNATIONAL ARBITRATION IN THE PRC AS A RESULT OF GLOBAL ECONOMIC INTEGRATION}

SUMMARY

The presented information on the arbitration system in China explains the growth of its popularity in the time of the hemispherical economic integration. Despite this there is a lack of adequate knowledge among many of the entrepreneurs operating in the Chinese market about the opportunities which the law gives to them. Acquiring this knowledge will, inter alia, increase the amount of contracts between enterprises, with appropriate clauses for arbitration. Relevant knowledge and experience will help to increase the efficiency of economic activities undertaken in China, enhance the economic growth of enterprises and increase the quantity and quality of international economic ties. 